\title{
Effect of Substituents on Cationic Polymerization of Six-Membered Spiro Orthocarbonates
}

\author{
Tatsuo Fujnami, Hisanori Tsuji, and Shizuyoshi SaKaI \\ Department of Industrial Chemistry, Faculty of Engineering, \\ Shizuoka University, Hamamatsu 432, Japan.
}

(Received March 11, 1977)

\begin{abstract}
Six-membered spiro orthocarbonates with methyl substituents were prepared from cyclic dibutylstannyl glycolates and carbon disulfide, then polymerized using boron trifluoride etherate as the catalyst in 1,2-dichloroethane at $30^{\circ} \mathrm{C}$. The methyl substituent caused a decrease in the polymer yield. The 2,8-dimethyl and 2,4,8,10-tetramethyl spiro monomers were polymerized by a 1,10-transfer reaction to bring about polyethercarbonates analogously to the unsubstituted spiro monomer. The spiro-monomer having 3,3,9,9-tetramethyl substituents underwent a 1,10-transfer polymerization at $30^{\circ} \mathrm{C}$ accompanied with the formation of polycarbonate segment which was partially depolymerized to the corresponding cyclic carbonate monomer at refluxing temperature of 1,2-dichloroethane. Contrary to the above, no polymer was obtained from the 2,2,4,8,8,10-hexamethyl spiro monomer.

KEY WORDS Spiro Orthocarbonate / Cationic Polymerization /

Transfer Polymerization / Substituent Effect / Polyethercarbonate /
\end{abstract}

Transfer polymerization of vinyl or cyclic monomers ${ }^{1-5}$ is a subject of considerable interest in polymer chemistry. The longest transfer reaction reported so far by other workers is the 1,8-transfer polymerization of spiro- orthocarboxylate, 1,4,6-trioxaspiro[4.4]nonane, catalyzed by the Lewis acid. ${ }^{5}$

Recently new synthetic methods for making spiro orthocarbonates as new heterocyclic monomer types have been established by us using
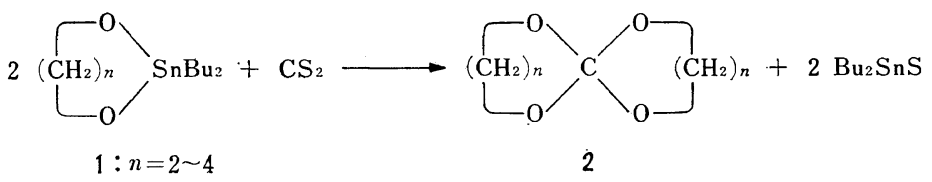

organostannyl $^{6,7}$ or tallous ${ }^{8}$ glycolate derivatives and carbon disulfide; a typical example for such a preparation is shown in eq 1 .

We reported already in our letter ${ }^{9}$ that cationic polymerization of the unsubstituted five- to sevenmembered spiro orthocarbonates (2) could be performed using boron trifluoride etherate $\left(\mathrm{BF}_{3} \mathrm{OEt}_{2}\right)$ as the catalyst in 1,2-dichloroethane at $30^{\circ} \mathrm{C}$, and that the ring size of the spiro monomer 2 strongly affected the mode of the polymerization reactions as indicated by eq 2. The seven-membered spiro monomer was

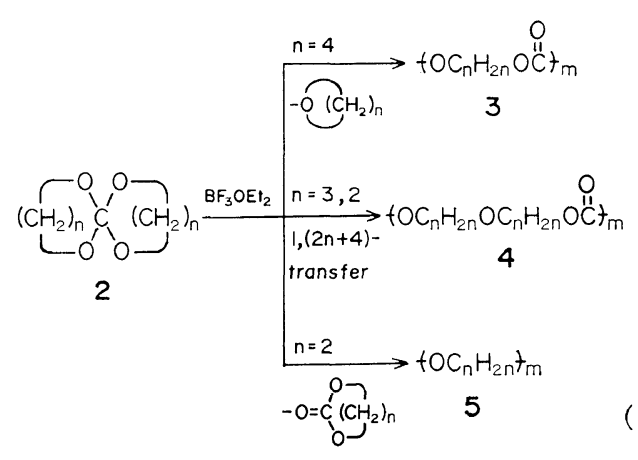


polymerized, eliminating the tetrahydrofuran to form polycarbonate $3(n=4)$, and the fivemembered spiro monomer was polymerized with a 1,8-transfer reaction to form the polyethercarbonate $4(n=2)$, but this was accompanied by the elimination of ethylene carbonate to form the polyether $5(n=2)$. In contrast to these polymerizations involving elimination reactions of cyclic ether or carbonate, the unsubstituted six-membered spiro orthocarbonate (2a; $n=3)$ was polymerized with a 1,10-transfer reaction to afford polyethercarbonate $4 \mathbf{a}(n=3)$. Such a type of 1,10-transfer polymerization of 2a is probably the longest transfer polymerization reported so far and a rare example of the homopolymerization of one kind of the monomer 2a to give an alternating structure which corresponds to the $1: 1$ copolymer of six-membered cyclic carbonate with four-membered cyclic ether.

Separate from our study regarding the preparation and polymerization of spiro orthocarbonates, Endo and Bailey reported that spiroorthocarbonates were polymerized without schrinkage during this process and showed the desirable character in these physical properties. ${ }^{10-12}$ However, our interest is directed to the reactivity and the mode of polymerization of 2 .

In this paper, we have reported on the preparation of methyl-substituted six-membered spiro orthocarbonate monomers $(\mathbf{2} \mathbf{b}-\mathbf{2 e})$, and studies on the influence of methyl substituents on the polymerizability and the mode of cationic ringopening polymerization.

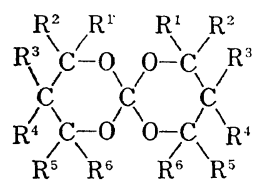

$$
\begin{aligned}
& 2 a ; R^{1}-R^{6}=H \\
& 2 b ; R^{1}=C_{3}, R^{2}-R^{6}=H \\
& 2 c ; R^{1}=R^{6}=C_{3}, R^{2}-R^{5}=H \\
& 2 d ; R^{1}=R^{2}=R^{5}=R^{6}=H, R^{3}=R^{4}=C_{3} \\
& 2 e ; R^{1}=R^{2}=R^{6}=\mathrm{CH}_{3}, R^{3}-R^{5}=H
\end{aligned}
$$

\section{EXPERIMENTAL}

\section{General}

No correction was made for any of the melting and boiling points. IR and NMR spectra were recorded with a JASCO IRA-1 and a Hitachi Perkin-Elmer R-24 spectrometer, respectively.

Glycols, dibutylstannyl oxide, and $\mathrm{BF}_{3} \mathrm{OEt}_{2}$ were commercially available and used without further purification. Carbon disulfide, 1,2dichloroethane, toluene, and hexane were dried in the usual manner.

Dibutylstannyl glycolates $(\mathbf{1 b}-\mathbf{1 c})$ were prepared from corresponding glycols and dibutylstannyl oxide by azeotropical dehydration in refluxing toluene similar to the method reported previously ${ }^{13}$ and were carefully dried by heating at $120^{\circ} \mathrm{C}$ under vacuum. As an exception, the glycolate 1e was prepared by reaction of 2methyl-2,4-pentanediol with diethoxydibutylstannane at $100^{\circ} \mathrm{C}$ with removal of the ethanol formed in vacuum. The melting and boiling points are as follows: 4-methyl-2-dibutylstanna1,3-dioxane (1b), $\mathrm{mp}$ (recrystallized from toluene) $97-100^{\circ} \mathrm{C}$ [1it. ${ }^{14}$ bp $165^{\circ} \mathrm{C}(0.25 \mathrm{~mm})$ ]; 4,6-dimethyl-2-dibutylstanna-1,3-dioxane (1c), bp $138^{\circ} \mathrm{C}$ $(0.3 \mathrm{~mm}) ; \quad 5,5$-dimethyl-2-dibutylstanna-1,3-dioxane (1d), $\mathrm{mp}$ (recrystallized from toluene) $108-111^{\circ} \mathrm{C} ; 4,4,6$-trimethyl-2-dibutylstanna-1,3dioxane $(1 \mathrm{e})$, bp $139^{\circ} \mathrm{C}(1.5 \mathrm{~mm})\left[\right.$ lit. $^{14} 143^{\circ} \mathrm{C}$ $(1.5 \mathrm{~mm})]$

The spiro-monomer, 1,4,6,10-tetraoxaspiro[4.5]decane (10), was prepared by the method appearing in the literature. ${ }^{6}$

\section{Preparation of 2,8-Dimethyl-1,5,7,11-tetraoxa- spiro[5.5]undecane $(\mathbf{2 b})$}

The dibutylstannyl glycolate $\mathbf{1 b}(32 \mathrm{~g}, 97 \mathrm{mmol})$, 1,2-dichloroethane $(25 \mathrm{~m} l)$ and slight excess amount of carbon disulfide $(10 \mathrm{ml})$ were introduced into a glass autoclave equipped with a mechanical stirrer under dry nitrogen, and the mixture was heated for $5 \mathrm{hr}$ at $85^{\circ} \mathrm{C}$. After evaporation of the excess carbon disulfide and the solvent, a large quantity of hexane was added to the reaction mixture to precipitate a small amount of yellow viscous liquid of the oligomeric material from 2 b. Following decantation to remove the liquid by-product and the subsequent evaporation of hexane from the mixture, $2.9 \mathrm{~g}(32 \%)$ of $\mathbf{2 b}$ were obtained by distillation under reduced pressure: bp $82-86^{\circ} \mathrm{C}$ $(1 \mathrm{~mm}) ; \mathrm{NMR}\left(\mathrm{CHCl}_{3}\right) \delta 1.24(\mathrm{~d}, 6, J=6.2 \mathrm{~Hz}$, $\left.\mathrm{CH}_{3}\right), 1.58\left(\mathrm{~m}, 4, \mathrm{CH}_{2}\right), 3.98\left(\mathrm{~m}, 4, \mathrm{OCH}_{2}\right)$, and $4.34 \mathrm{ppm}(\mathrm{m}, 2, \mathrm{OCH})$; IR $\left(\mathrm{CHCl}_{3}\right) 1130$ and $1015 \mathrm{~cm}^{-1}\left(\nu_{\mathrm{C}-\mathrm{O}}\right)$. 
Preparation of 2,4,8,10-Tetramethyl-1,5,7,11tetraoxaspiro[5.5] undecane $(2 \mathrm{c})$

Glycolate 1c was allowed to react with carbon disulfide for $10 \mathrm{hr}$ at $90^{\circ} \mathrm{C}$, as in the case of 2b. After evaporation of carbon disulfide and the solvent, a considerable amount of hexane was added to precipitate a white solid of $\mathbf{2 c}$ : yield 27\%; $\mathrm{mp}\left(\mathrm{CCl}_{4}\right) \quad 153-155^{\circ} \mathrm{C}$; NMR $\left(\mathrm{CHCl}_{3}\right) \delta 1.23\left(\mathrm{~d}, 12, J=6.2 \mathrm{~Hz}, \mathrm{CH}_{3}\right) 1.49$ $\left(\mathrm{m}, 4, \mathrm{CH}_{2}\right)$, and $4.16 \mathrm{ppm}(\mathrm{m}, 4, \mathrm{CH})$; IR $\left(\mathrm{CHCl}_{3}\right) 1100$ and $1025 \mathrm{~cm}^{-1}\left(\nu_{\mathrm{C}-\mathrm{o}}\right)$.

Preparation of 3,3,9,9-Tetramethyl-1,5,7,11tetraoxaspiro[5.5] undecane $(2 \mathrm{~d})$

The glycolate 1d was allowed to react with carbon disulfide for $13 \mathrm{hr}$ at $85^{\circ} \mathrm{C}$, and the reaction mixture was worked-up as mentioned above to afford the white crystal 2d: yield 56\%; $\mathrm{mp}\left(\mathrm{CCl}_{4}\right) 138-140^{\circ} \mathrm{C}$; NMR $\delta 0.99\left(\mathrm{~s}, 12, \mathrm{CH}_{3}\right)$ and $3.65 \mathrm{ppm}\left(\mathrm{s}, 8, \mathrm{CH}_{2}\right)$; IR $\left(\mathrm{CHCl}_{3}\right) 1115$ and $1010 \mathrm{~cm}^{-1}\left(\nu_{\mathrm{C}-0}\right)$.

Preparation of 2,2,4,8,8,10-Hexamethyl-1,5,7,11tetraoxaspiro[5.5]undecane (2e)

The glycolate 1e was allowed to react with carbon disulfide for $13 \mathrm{hr}$ at $110^{\circ} \mathrm{C}$. The reaction mixture was distilled giving a colorless liquid of 2e: yield 52\%; bp $102-104^{\circ} \mathrm{C}(5 \mathrm{~mm})$; NMR $\left(\mathrm{CHCl}_{3}\right) \delta 1.21(\mathrm{~d}, 6, J=5.6 \mathrm{~Hz}, 4-$ and $10-\mathrm{CH}_{3}$ ), 1.29 (s, 12, 2- and $\left.8-\mathrm{CH}_{3}\right) 1.39$ (d, 4, $\left.J=6.1 \mathrm{~Hz}, \mathrm{CH}_{2}\right)$, and $4.20 \mathrm{ppm}(\mathrm{m}, 2, \mathrm{CH})$; IR $\left(\mathrm{CHCl}_{3}\right) 1125$ and $1025 \mathrm{~cm}^{-1}\left(\nu_{\mathrm{C}-0}\right)$.

\section{Polymerization of Spiro Orthocarbonates}

Generally, the spiro monomer $(3 \mathrm{mmol})$ and $\mathrm{BF}_{3} \mathrm{OEt}_{2} \quad(1-8 \mathrm{~mol} \%$ based on 2 ; mainly 4 $\mathrm{mol} \%)$ in 1,2-dichloroethane $(3 \mathrm{ml})$ were sealed in a glass tube under dry nitrogen and held at $30.0 \pm 0.1^{\circ} \mathrm{C}$. After the polymerization reaction was stopped by adding a few drops of $10-\%$ diethylamine in 1,2-dichloroethane, the solvent and the unreacted monomer were evaporated under vacuum at $50-100^{\circ} \mathrm{C}$ to give the corresponding polymer as a colorless viscous material. The mean molecular weights measured by GPC were 5600 and 4800 for the polymers from 2a and $\mathbf{2 d}$, respectively, and less than 4000 for that from $\mathbf{2 b}$ or $\mathbf{2 c}$.

The monomer 2d was also polymerized in refluxing 1,2-dichloroethane using $\mathrm{BF}_{3} \mathrm{OEt}_{2}$ as catalyst. After the polymerization reaction was stopped by addition of diethylamine and the solvent was evaporated, the tetramer and the polymer of 3,3-dimethyloxetane were extracted with hexane, and then the monomer $2 d$ and the cyclic carbonate, 5,5-dimethyl-1,3-dioxan-2one (9d), were sublimed under vacuum at 50$100^{\circ} \mathrm{C}$ to give the polymer as a viscous material. The tetramer of 3,3-dimethyloxetane was sublimed under vacuum at $130^{\circ} \mathrm{C}$ from the soluble products in hexane and the residual material contained the polyether: tetramer; $\mathrm{mp} 153$ $156^{\circ} \mathrm{C}$ (lit. ${ }^{15} 157^{\circ} \mathrm{C}$ ); NMR $\left(\mathrm{CHCl}_{3}\right) \delta 0.83$ (s, $\left.\mathrm{CH}_{3}\right)$ and $3.08 \mathrm{ppm}$ (s, $\left.\mathrm{CH}_{2}\right)$; IR $\left(\mathrm{CHCl}_{3}\right)$ $1139 \mathrm{~cm}^{-1}\left(\nu_{\mathrm{C}-\mathrm{o}}\right)$ : polyether; NMR $\left(\mathrm{CHCl}_{3}\right) \delta$ $0.87\left(\mathrm{~s}, \mathrm{CH}_{3}\right)$ and $3.11 \mathrm{ppm}\left(\mathrm{s}, \mathrm{CH}_{2}\right)$; IR $\left(\mathrm{CHCl}_{3}\right)$ $1131 \mathrm{~cm}^{-1}\left(\nu_{\mathrm{C}-\mathrm{O}}\right)$. The NMR and IR spectra of the carbonate 9d were coincident with those of an authentic sample.

\section{Hydrolysis of the Polymer Obtained from $2 \boldsymbol{b}$}

To a solution of the polymer $4 \mathrm{~b}(0.20 \mathrm{~g})$ in aqueous $20-\%$ ethanol $(5 \mathrm{~m} l)$ was added sodium hydroxide $(0.5 \mathrm{~g})$. The homogeneous solution was refluxed for $2 \mathrm{hr}$. After neutralization of the solution with diluted hydrochloric acid, the hydrolyzed product was extracted repeatedly with chloroform. The extract was washed with a small amount of water and dried with anhydrous sodium sulfate. Evaporation of chloroform gave the glycol $\mathrm{HOCH}\left(\mathrm{CH}_{3}\right) \mathrm{CH}_{2} \mathrm{CH}_{2} \mathrm{OCH}$ $\left(\mathrm{CH}_{3}\right) \mathrm{CH}_{2} \mathrm{CH}_{2} \mathrm{OH}(6 ; 0.14 \mathrm{~g})$ which was determined as not involving any other glycol by GLC; IR $\left(\mathrm{CHCl}_{3}\right) 1080\left(\nu_{\mathrm{C}-0}\right)$ and $3460 \mathrm{~cm}^{-1}$ $\left(\nu_{\mathrm{OH}}\right)$.

The glycol 6 was acetylated by refluxing acetic anhydride in pyridine to form the diacetate $\mathrm{CH}_{3} \mathrm{COOCH}\left(\mathrm{CH}_{3}\right) \mathrm{CH}_{2} \mathrm{CH}_{2} \mathrm{OCH}\left(\mathrm{CH}_{3}\right)$ $\mathrm{CH}_{2} \mathrm{CH}_{2} \mathrm{OCOCH}_{3} ; \mathrm{NMR}\left(\mathrm{CHCl}_{3}\right) \delta 1.13$ (d, 3, $\left.J=6.0 \mathrm{~Hz}, \mathrm{CH}_{3} \mathrm{C}-\mathrm{O}\right), 1.23(\mathrm{~d}, 3, J=6.0 \mathrm{~Hz}$, $\mathrm{CH}_{3} \mathrm{C}-\mathrm{OCO}$ ), 1.74 (m, 4, $\mathrm{CH}_{2}-\mathrm{C}$ ), 2.00 (s, 6, $\mathrm{CH}_{3} \mathrm{COO}$ ), 3.38 (t, $2, J=6.4 \mathrm{~Hz}, \mathrm{CH}_{2}-\mathrm{O}$ ), 3.5 $(\mathrm{m}, 1, \mathrm{CH}-\mathrm{O}), 4.11\left(\mathrm{t}, 2, J=6.6 \mathrm{~Hz}, \mathrm{CH}_{2}-\right.$ $\mathrm{OCO}$ ), and $4.97 \mathrm{ppm}(\mathrm{m}, 1, \mathrm{CH}-\mathrm{OCO})$; IR $\left(\mathrm{CHCl}_{3}\right) 1735 \mathrm{~cm}^{-1}\left(\nu_{\mathrm{C}=0}\right)$.

\section{Solid-State Polymerization of Unsubstituted Mono- mer $2 a$}

Solid-state polymerization of crystalline monomer $2 \mathrm{a}(0.2 \mathrm{~g})$ was carried out in hexane $(2 \mathrm{ml})$ at $-10-30^{\circ} \mathrm{C}$ using $\mathrm{BF}_{3} \mathrm{OEt}_{2}(0.023 \mathrm{~mol} / \mathrm{l})$ as the catalyst. A viscous polymer was obtained after working-up the polymerization mixture in 
the manner mentioned above.

Polymerization of crystalline monomer 2a was also examined with $\gamma$-ray irradiation in a sealed tube under dry nitrogen at room temperature. No polymer was obtained at a total dose of $10^{4}-10^{6} \mathrm{r}$.

\section{RESULTS AND DISCUSSION}

\section{Preparation of Spiro Monomers}

Six-membered spiro orthocarbonates $(\mathbf{2 b}-\mathbf{2} \mathbf{e})$ substituted by methyl groups were successfully prepared by the reaction of dibutylstannyl glycolates $(\mathbf{1 b}-\mathbf{1 e})$ with carbon disulfide analogously to the preparation of the unsubstituted monomer $2 \mathrm{a}^{2}$ (eq 1), and the results are shown in Table I.

The yields and reaction conditions described in Table $I$ indicate that the reaction for the preparation of $\mathbf{2}$ was affected by the methyl substituent. Symmetric spiro orthocarbonates, $\mathbf{2 a}, \mathbf{2 c}$, and $\mathbf{2 d}$, were obtained as solids, but the unsymmetric $\mathbf{2 b}$ and $\mathbf{2 e}$ were liquids. Al- though orthocarbonate is known to be an organic dehydrating agent, 3,3,9,9-tetramethylsubstituted monomer 2d was exceptionally stable in the moisture of the air.

Polymerizability of the Substituted Spiro Orthocarbonates

The cationic polymerization of the substituted spiro-monomers was carried out in 1,2dichloroethane using $\mathrm{BF}_{3} \mathrm{OEt}_{2}$ as the catalyst. Yields of polymers and the polymerization conditions are summarized in Table II.

Methyl substituents in the monomer caused the polymerizability to decrease, so that the apparent rates of polymerization have the following order: $\mathbf{2 a}>\mathbf{2 b}>\mathbf{2 c}, \mathbf{2 d}>\mathbf{2 e}$. The most bulky monomer $2 \mathbf{e}$ did not allow formation of a polymer even within the long period of the polymerization time.

Characterization of the Polymers Formed and Modes of Polymerizations

The polymer obtained from 2,8-dimethyl-

Table I. Preparation of six-membered spiro orthocarbonates

\begin{tabular}{|c|c|c|c|c|}
\hline \multirow{2}{*}{$A$ in } & \multicolumn{2}{|c|}{ Condition } & \multirow{2}{*}{$\begin{array}{c}\text { Yield, } \\
\%\end{array}$} & \multirow{2}{*}{$\begin{array}{c}\mathrm{mp},{ }^{\circ} \mathrm{C} \\
\left(\mathrm{bp},{ }^{\circ} \mathrm{C} / \mathrm{mm}\right)\end{array}$} \\
\hline & Temp, ${ }^{\circ} \mathrm{C}$ & Time, hr & & \\
\hline$-\mathrm{CH}_{2} \mathrm{CH}_{2} \mathrm{CH}_{2}-(\mathbf{2 a})^{\mathrm{a}}$ & 105 & 10 & 92 & $132-133$ \\
\hline$-\mathrm{CH}\left(\mathrm{CH}_{3}\right) \mathrm{CH}_{2} \mathrm{CH}_{2}-(\mathbf{2 b})$ & 85 & 5 & 32 & $(82-86 / 1)$ \\
\hline$-\mathrm{CH}\left(\mathrm{CH}_{3}\right) \mathrm{CH}_{2} \mathrm{CH}\left(\mathrm{CH}_{3}\right)-(2 \mathrm{c})$ & 90 & 10 & 27 & $153-155$ \\
\hline$-\mathrm{CH}_{2} \mathrm{C}\left(\mathrm{CH}_{3}\right)_{2} \mathrm{CH}_{2}-(\mathbf{2 d})$ & 85 & 13 & 56 & $138-140$ \\
\hline$-\mathrm{C}\left(\mathrm{CH}_{3}\right)_{2} \mathrm{CH}_{2} \mathrm{CH}\left(\mathrm{CH}_{3}\right)-(2 \mathrm{e})$ & 110 & 13 & 52 & $(102-104 / 5)$ \\
\hline
\end{tabular}

a Data from ref 7 .

Table II. Polymerization of six-membered spiro orthocarbonates

\begin{tabular}{|c|c|c|c|c|}
\hline 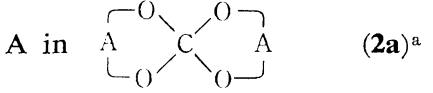 & $\begin{array}{l}\mathrm{BF}_{3} \mathrm{OEt}_{2} \\
\mathrm{~mol} \%\end{array}$ & $\underset{{ }^{\circ} \mathrm{C}}{\mathrm{Temp}}$ & $\underset{\mathrm{hr}}{\mathrm{Time}}$ & $\begin{array}{c}\text { Polymer yield, } \\
\text { wt } \%\end{array}$ \\
\hline$-\mathrm{CH}_{2} \mathrm{CH}_{2} \mathrm{CH}_{2}-(\mathbf{2 a})^{b}$ & 1 & 30 & 16 & 91 \\
\hline \multirow{2}{*}{$-\mathrm{CH}\left(\mathrm{CH}_{3}\right) \mathrm{CH}_{2} \mathrm{CH}_{2}-(2 \mathbf{b})$} & 4 & 30 & 24 & 50 \\
\hline & 4 & 30 & 148 & 75 \\
\hline \multirow[t]{2}{*}{$-\mathrm{CH}\left(\mathrm{CH}_{3}\right) \mathrm{CH}_{2} \mathrm{CH}\left(\mathrm{CH}_{3}\right)-(2 \mathrm{c})$} & 4 & 30 & 240 & 9 \\
\hline & 4 & 30 & 720 & 42 \\
\hline \multirow{2}{*}{$-\mathrm{CH}_{2} \mathrm{C}\left(\mathrm{CH}_{3}\right)_{2} \mathrm{CH}_{2}-(\mathbf{2 d})$} & 4 & 30 & 168 & 13 \\
\hline & 8 & reflux & 0.5 & 45 \\
\hline$-\mathrm{C}\left(\mathrm{CH}_{3}\right)_{2} \mathrm{CH}_{2} \mathrm{CH}\left(\mathrm{CH}_{3}\right)-(2 \mathbf{e})$ & 4 & 30 & 240 & 0 \\
\hline
\end{tabular}

a $1.0 \mathrm{~mol} / \mathrm{l}$ of 1,2 -dichloroethane.

b Data from ref 9. 
substituted monomer $\mathbf{2 b}$ had the characteristic bands of a carbonate structure at $1740 \mathrm{~cm}^{-1}$ and ether band at $1125 \mathrm{~cm}^{-1}$. The NMR spectrum showed three pairs of signals whose areas were neary the same. The signal observed at a higher field are reasonably assigned to the methyl, methylene, and methine protons related to the ether linkage: $\delta 1.15\left(\mathrm{~d}, 3, J=6.2 \mathrm{~Hz}, \mathrm{CH}_{3}\right.$ $\mathrm{C}-\mathrm{O}-\mathrm{C}$ ), 3.43 (t, 2, J=6.1 Hz, $\mathrm{CH}_{2}-\mathrm{O}-\mathrm{C}$ ), and $3.6 \mathrm{ppm}(\mathrm{m}, 1, \mathrm{CH}-\mathrm{O}-\mathrm{C})$. Those at a lower field are assignable to the groups related to the carbonate linkage: $\delta 1.30(\mathrm{~d}, 3, J=6.2$ $\mathrm{Hz}, \mathrm{CH}_{3}-\mathrm{C}-\mathrm{OCOO}$ ), $4.18(\mathrm{t}, 2, J=6.3 \mathrm{~Hz}$, $\mathrm{CH}_{2}-\mathrm{OCOO}$ ), and $4.86 \mathrm{ppm}(\mathrm{m}, 1, \mathrm{CH}-\mathrm{OCOO}$ ). The 3- and 9-methylene protons appeared at $\delta$ $1.78 \mathrm{ppm}\left(\mathrm{m}, 4, \mathrm{C}-\mathrm{CH}_{2}-\mathrm{C}\right)$. From these spectroscopic data, it is demonstrated that the monomer $\mathbf{2 b}$ gives the polyethercarbonate $\mathbf{4 b}$ in the cationic polymerization. Additional evidence for this structure $\mathbf{4 b}$ was provided by alkaline hydrolysis of the polymer. The hydrolyzed product was only the glycol 6 whose structure was confirmed by the NMR spectrum as to its diacetate.

Thus the cationic polymerization of $\mathbf{2 b}$ is represented by the 1,10-transfer reaction analogous to the polymerization of the unsubstituted monomer $\mathbf{2 a}$, as formulated in eq 3 .

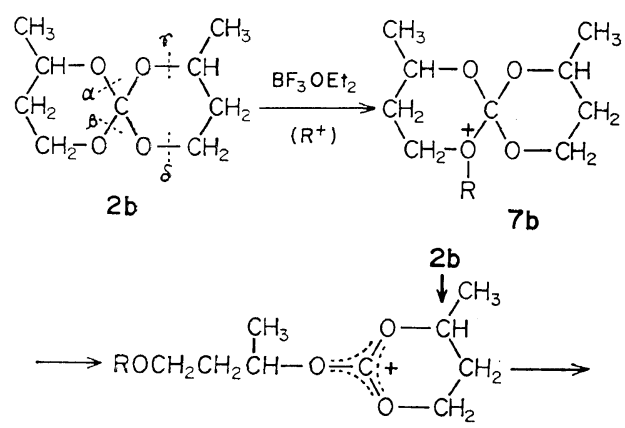

$8 b$

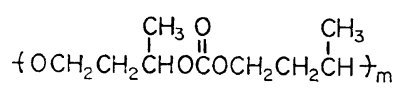

$4 b$

$4 \mathrm{~b} \stackrel{\mathrm{OH}^{-} / \mathrm{H}_{2} \mathrm{O}}{\longrightarrow} \mathrm{HOCH}_{2} \stackrel{\stackrel{\mathrm{CH}_{2}}{\mathrm{C}} \mathrm{CHOCH}}{\mathrm{CHOCH}} \stackrel{\stackrel{\mathrm{CH}}{\mathrm{C}} \mathrm{CH}_{2} \mathrm{CHOH}}{\mathrm{CH}}$
Generally, it has been observed that cationic ring-opening reactions of $\alpha$-methyl-substituted cyclic ether, such as propylene oxide, undergo two comparable fissions of the methyl-substituted and unsubstituted carbon-oxygen bonds. ${ }^{16,17}$ In the cationic 1,10-transfer polymerization of the monomer $\mathbf{2 b}$, four modes of the ring opening may be possible according to the two positions of attack by an active species and those of the bond fissions; $\alpha-\gamma, \alpha-\delta, \beta-\gamma$, and $\beta-\delta$ fissions in 2 b.

From the structure $\mathbf{4 b}$ of the polymer obtained, $\alpha-\gamma$ and $\beta-\delta$ fissions are excluded, and ring-opening mode of $\alpha-\delta$ or of $\beta-\gamma$ fission is considered to be predominant. It is reasonably postulated that the monomer $\mathbf{2 b}$ may be attacked with an electrophile (catalyst) at the oxygen of 5 -position to cause the $\beta$-fission because of the smaller steric hindrance. And, a nucleophilic attack by the monomer may easily occur on the methyl-substituted carbon at 8-position in $\mathbf{8 b}$ to cause the $\gamma$-fission because of increasing carbonium-ion character at the methyl-substituted carbon atom in the trioxocarbonium ion $\mathbf{8 b}$. A similar mode of attack of a monomer on the methyl-substituted carbon of an dioxocarbonium ion intermediate was reported in the case of the cationic ring-opening polymerization of 4methyl-2-vinyl-1,3-dioxolane. ${ }^{18}$

The IR spectrum of the polymer obtained from 2,4,8,10-tetramethyl-substituted monomer 2c showed the bands at $1740\left(\nu_{\mathrm{C}=0}\right)$ and 1125 $\mathrm{cm}^{-1}\left(\nu_{\mathrm{C}-\mathrm{O}}\right)$. The NMR spectrum also showed two pairs of signals related to the ether and carbonate structures: $\delta 1.23(\mathrm{~d}, J=6.0 \mathrm{~Hz}$, $\left.\mathrm{CH}_{3}-\mathrm{C}-\mathrm{O}-\mathrm{C}\right), 3.66(\mathrm{~m}, 2, \mathrm{CH}-\mathrm{O}-\mathrm{C}), 1.32$ (d, $J=7.0 \mathrm{~Hz}, \mathrm{CH}_{3}-\mathrm{C}-\mathrm{OCOO}$ ), and $4.93 \mathrm{ppm}$ $\mathrm{m}, 2, \mathrm{CH}-\mathrm{OCOO}$ ). The 3- and 9-methylene protons appeared at $\delta 1.54 \mathrm{ppm}$. It is supposed

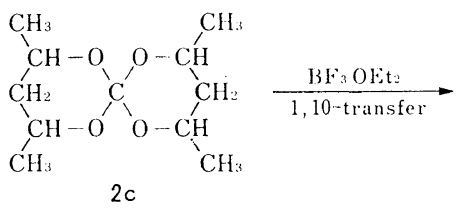

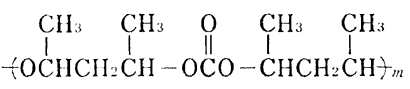

$4 c$ 
that the monomer $2 \mathrm{c}$ is also polymerized with 1,10 -transfer reaction to give the polyethercarbonate having the structure $4 \mathrm{c}$, as shown in eq 5 .

The monomer having four methyl groups at 3,3,9 and 9-positions was found to be polymerized in a complicated way, using $\mathrm{BF}_{3} \mathrm{OEt}_{2}$ in 1,2-dichloroethane at $30^{\circ} \mathrm{C}$. The colorless viscous polymer was obtained and it showed $\nu_{\mathrm{C}=0}\left(1745 \mathrm{~cm}^{-1}\right)$ and $\nu_{\mathrm{C}-\mathrm{o}}\left(1130 \mathrm{~cm}^{-1}\right)$ bands in the IR spectrum, and two singlets of methylenes at $\delta 3.15\left(\mathrm{CH}_{2}-\mathrm{O}-\mathrm{C}\right)$ and $3.98 \mathrm{ppm}\left(\mathrm{CH}_{2}-\right.$ $\mathrm{OCOO}$ ) in the NMR spectrum. The area of the former peak was smaller than that of the latter in the NMR spectrum. It has been suggested that the polyethercarbonate structure $\mathbf{4 d}$ was formed with the formation of the polycarbonate structure 3d. Moreover, two singlets observed at $\delta 0.99$ and $0.93 \mathrm{ppm}$ were assignable to methyl protons in $\mathbf{3 d}$ and in $\mathbf{4 d}$, respectively. Therefore, the polymerization mode of the monomer 2d is shown by eq 6 , which is concerned with the 1,10-transfer reaction to form 4d and with the elimination reaction of 3,3dimethyloxetane to form 3d. It has been known that 3,3-dimethyloxetane easily polymerizes in the presence of a cationic catalyst to give a mixture of the tetramer and the polyether. ${ }^{15}$ These products were also obtained in the polymerization of $2 \mathbf{d}$ to support the elimination of 3,3-dimethyloxetane.

The 1,10-transfer polymerization of $2 \mathrm{~d}$ may require the more sterically hindered $\mathbf{M}$-attack by the ether-oxygen atom in the monomer $\mathbf{2 d}$ to the propagating terminal in $8 \mathbf{d}$ in eq 6 , because the electron pair of oxygen atom at nucleophilically attacking point in the monomer 2d is located at the 1,3-diaxial position against the 3- or 9- dimethyl group, and the electrophilic point $\mathbf{M}$ is located adjacently to the tertiary carbon in $\mathbf{8 d}$. On the other hand, the L-attack of $2 \mathbf{d}$ to the trioxocarbonium ion $\mathbf{8 d}$ should be favored to form the segment of $\mathbf{3 d}$,
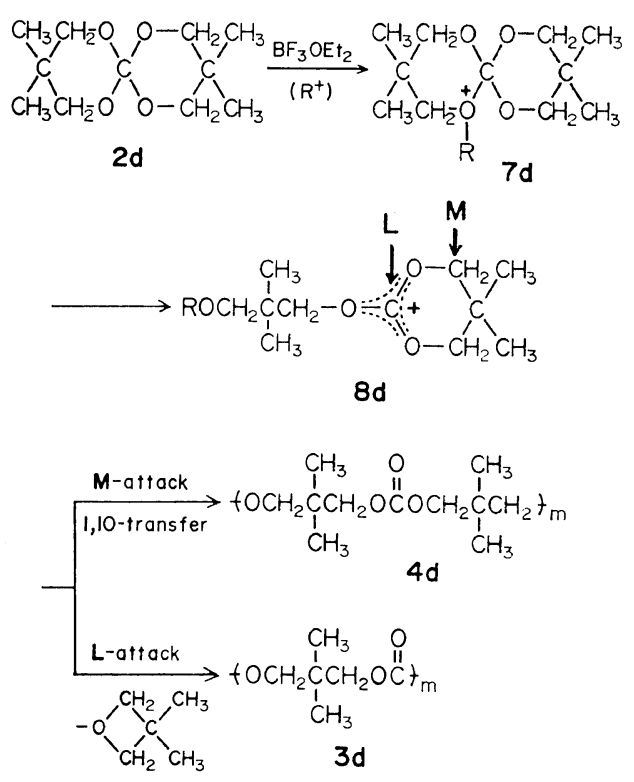

because the L-attack is probably unaffected by steric hindrance through elimination of the oxetane.

The monomer $2 d$ was also polymerized in refluxing 1,2-dichloroethane using $\mathrm{BF}_{3} \mathrm{OEt}_{2}$ as catalyst. The polymer showed similar NMR and IR spectra mentioned above. The yield and composition of the polymer are plotted against the polymerization time in Figure 1 . The yield reached a maximum value after the polymerization for $20 \mathrm{~min}$, and then gradually decreased. The content of the polycarbonate unit 3d also decreased. It has been known that the polycarbonate $\mathbf{3 d}$ is depolymerized by heating to afford the cyclic carbonate 9d. ${ }^{19}$ So, the decrease in the polymer yield is reasonably explained by the depolymerization of 3d-type sequence formed in the early stage of the polymerization (eq 7). The carbonate 9d was isolated by sublimation from the polymerization mixture in vacuo.

The monomer $2 \mathrm{e}$ having six methyl substituents<smiles>CC(C)(C=O)COC(=O)CCCC(=O)OCC(C)(C)C(=O)OCC(C)(C)C=O</smiles> 


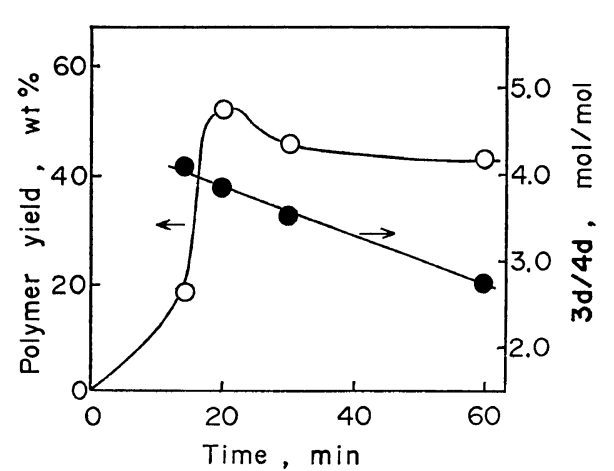

Figure 1. Polymerization of 3,3,9,9-tetramethylsubstituted six-membered spiro orthocarbonate (2d) catalyzed by $\mathrm{BF}_{3} \mathrm{OEt}_{2}$ in refluxing 1,2-dichloroethane: monomer, $1.0 \mathrm{~mol} / l ; \mathrm{BF}_{3} \mathrm{OEt}_{2}, \quad 8 \mathrm{~mol} \%$ based on $\mathbf{2 d}$.

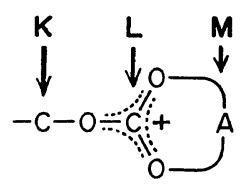

8

at the 2,2,4,8,8, and 10-positions could not be polymerized due to the large steric hindrance. A variety of cationic polymerization reactions of spiro orthocarbonates are represented in terms of the ambident nature of the heterocyclic trioxocarbonium ion $\mathbf{8}$. The monomer is able to react at the positions $\mathbf{K}, \mathbf{L}$, and $\mathbf{M}$.

Methyl substituents of the spiro monomers affect the reactivities and the modes of polymerization. Methyl substituents in the $\alpha$-position from the oxygen atom decreased the polymerizability of six-membered spiro orthocarbonates, but dit not affect the mode of polymerization. Therefore, the 1,10-transfer polymerization occurred in the case of $\alpha$-substituted spiro monomers. Contrary to this, methyl substituents in the $\beta$-position decreased the polymerizability of the monomer $\mathbf{2 d}$ and strongly affected the mode of polymerization.

\section{Other Related Polymerizations}

The unsymmetric spiro orthocarbonate $\mathbf{1 0}$ consisting of six- and five-membered rings was also polymerized using $\mathrm{BF}_{3} \mathrm{OEt}_{2}$ as the catalyst in 1,2-dichloroethane for $4 \mathrm{hr}$ at $30^{\circ} \mathrm{C}$ to afford colorless viscous material in $76-\%$ yield. The IR spectrum of the polymer showed bands of $\nu_{\mathrm{C}=\mathrm{O}}\left(1753 \mathrm{~cm}^{-1}\right)$ and $\nu_{\mathrm{C}-\mathrm{O}}\left(1124\right.$ and $\left.1049 \mathrm{~cm}^{-1}\right)$. The NMR spectrum showed signals at $\delta 1.94$ (m, 2, C- $\mathrm{CH}_{2}-\mathrm{C}$ ), 3.51, 3.58 (two t, 4, $\mathrm{CH}_{2} \mathrm{O}$ ) and $4.25 \mathrm{ppm}$ ( $\left.\mathrm{t}, 4, \mathrm{CH}_{2}-\mathrm{OCOO}\right)$. These data are in agreement with the polyethercarbonate structure $\mathbf{1 1}$ formed by a 1,9-transfer polymerization of $\mathbf{1 0}$, as shown in eq 8 .

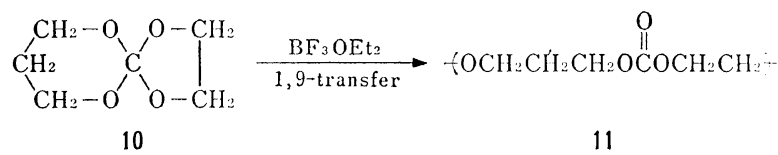

J. Am. Chem. Soc., 79, 3760 (1957).

The polymerization of the monomer $2 \mathbf{a}$ was examined in the solid state. In hexane, the crystalline monomer $\mathbf{2 a}$ was polymerized using $\mathrm{BF}_{3} \mathrm{OEt}_{2}$ as catalyst at $-10-30^{\circ} \mathrm{C}$ to give the polyethercarbonate $\mathbf{4 a}$ as a viscous liquid. This result could not be distinguished from that of the homogeneous polymerization in solution. The crystalline monomer $2 \mathbf{a}$ was irradiated with $\gamma$-ray in dry nitrogen at a total dose of $10^{4}$ $10^{6} \mathrm{r}$; however, no reaction was observed.

\section{REFERENCES}

1. D. S. Breslow, G. E. Hulse, and A. S. Matlack,
2. T. Takahashi and I. Yamashita, J. Polym. Sci., Polym. Lett. Ed., 3, 255 (1965).

3. L. A. Errede, J. Polym. Sci., 49, 253 (1961).

4. T. Mukaiyama, T. Fujisawa, H. Nohira, and T. Hyuga, J. Org. Chem., 27, 3337 (1962).

5. K. Bodenbener, Ann., 623, 183 (1959).

6. S. Sakai, Y. Kiyohara, K. Itoh, and Y. Ishii, J. Org. Chem., 35, 2347 (1970).

7. S. Sakai, Y. Kobayashi, and Y. Ishii, J. Org. Chem., 36, 1176 (1971).

8. S. Sakai, Y. Kuroda, and Y. Ishii, J. Org. Chem., 37, 4198 (1972).

9. S. Sakai, T. Fujinami, and S. Sakurai, $J$. 
Poiym. Sci., Polym. Lett. Ed., 11, 631 (1973).

10. T. Endo and W. J. Bailey, Makromol. Chem., 176, 2897 (1975).

11. T. Endo and W. J. Bailey, J. Polym. Sci., Polym. Chem. Ed., 13, 2525 (1975).

12. W. J. Bailey and T. Endo, J. Polym. Sci., Polym. Chem. Ed., 14, 1735 (1976).

13. J. Bornstein, B. R. LaLiBerter, T. M. Andrews, and J.C. Montermoss, J. Org. Chem., 24, 886 (1959).

14. R. C. Mehrotra and V. D. Gupta, J. Organometal. Chem., 4, 145 (1965).
15. J. B. Rose, J. Chem. Soc., 542 (1956).

16. M.S. Newman, "Steric Effects in Organic Chemistry," J. Wiley and Sons, Inc., New York, N.Y., 1956, p 106.

17. Y. Ishii and S. Sakai, "Ring-Opening Polymerization," K. C. Frisch and S. L. Reegen, Ed., M. Dekker, Inc., New York, N.Y., 1969, p 13.

18. J. D. Nordstrom, J. Polym. Sci., Part A-1, 7, 1349 (1969).

19. S. Sarel and L. Pohoryles, J. Am. Chem. Soc., 80, 4596 (1958). 